\title{
The Importance of Community Engagement in Education Management in Early Childhood Education in 4.0 Era
}

\author{
Eravia
}

Padang State University, Padang - Indonesia, eraviaveronica@gmail.com

\begin{abstract}
Early childhood education aims to develop the basis of intelligence, knowledge, personality, noble character, and skills to attend education among children aged 4-6 years, called the age of gold. Community involvement in school development is fitting, because education is part of the essence of people's lives. The community has interests not just in school development, but primarily to improve quality in the framework of forming social roles through various forms of participation in early childhood education institutions. Community involvement in school activities is a feature of good relationships between schools and communities, meaning that the extent to which the community can be empowered in the education process in schools is an indicator of the school management in question.
\end{abstract}

Keywords: Society, Public Relations, Early Childhood Education

\section{INTRODUCTION}

Early Childhood Education (ECE) is an approach to development that is aimed at children from birth to the age of 6 (six) years which is done through the provision of stimulus education to assist the growth and development of the physical and spiritual so that children have the readiness to enter further education (Permendikbud, 2015)

Early childhood provides a clear picture that there are age limits in children which are very necessary, especially in the world of education. Because each development period requires different methods and materials according to their respective stages of development. Early childhood has begun to recognize social interactions, need friends to play and begin to form characters (Tatli et al., 2018).

Early childhood is often called the golden age (golden age). In this golden age, the child's brain's ability to receive all knowledge from the surrounding environment is followed by a very high curiosity. This curiosity is shown by children actively asking questions about things they have met or got (Abalı \& Kaan, 2018). The importance of early childhood education and its role in shaping young minds is widely recognized, especially its impact on creativity. Gardner states, "I consider the period from two to six or seven years to be a very constructive period for children's development (Kiewra \& Veselack, 2016).

Parent involvement in school activities is a hallmark of a good relationship between school and parents, meaning that the extent to which the community can be empowered in the education process at school is an indicator of the school management concerned. Community empowerment in education is an educational program that must be carried out. Participation masyar a kat big influence on the progress and the existence of schools (Fordham, 2015)

The role of the community in educational institutions actually bi sa help neutralize the issue of school. There are two functions of public relations within the institution, namely internal and external functions. Internal function is to build information to parties in institutions at each level (Tallent \& Barnes, 2015). While the external function of Public Relations is more directed to outsiders such as the community, parents and the department in conflict. tasks such as fostering, managing and developing relationships with school committees, fostering development between schools and government institutions, the business world and other social institutions (Çoruk, 2018).

The importance of community relations is to get overall support in all fields of education, especially PAUD institutions. The high growth of PAUD institutions makes the importance of PR in PAUD institutions, because the relationship with the community is the initial spearhead of the ongoing education which affects $90 \%$ of the sustainability and existence of an educational institution. Public Relations is an activity carried out jointly between institutions and the community to gain understanding, trust, appreciation, harmonious relations, as well as conscious and voluntary support. Public relations activities 
carried out by institutions to serve the interests of education. at school, the activity is called public relations.

Educational public relations activities or more concrete relations between schools and the community have a background in thinking that is no different from public relations activities in general. Therefore, the process of activities and important principles in public relations need to receive proper attention when the school has relations with the community. Community relations carried out by PAUD institutions and stakeholders take place in an atmosphere of mutual need so that the effectiveness of success is great (Gleason \& Violette, 2012).

But for the implementation of community engagement programs in PAUD is not an easy thing. Many reasons can become obstacles in this community engagement program. These reasons are not intentional reasons, but they usually appear logically and in accordance with real circumstances. Starting from the lack of resources specifically in their fields, and the lack of funding for the program.

According to Suriansyah (2014: 64) in practice the relationship between schools and the community in the context of increasing the involvement or participation of parents / families in education in schools encountered a number of obstacles. These obstacles can come from the perspective of teachers and principals as implementing relationships and from the community as subjects who are invited to be directly involved in various school activities in order to improve school quality.

Grant and Ray (Suriansyah, 2014: 64) stated that there were a number of obstacles encountered in building family involvement in schools including aspects: economics, selfefficacy, intergeneration, time demand, cultural norms and value class room culture and past experience.

1. Economics (lack of money and transportation) economy (lack of money and transportation).

2. Self-efficacy (lack of confident in ability to help, language consideration) / own happiness (lack of confidence in ability to help, language consideration).

3. Intergenerational factors (their parents uninvolved) / intergenerational factors (their parents are not involved).

4. Time demands (work related, child care, elder care) / time demand factors that are related to work, child care, parental care.

5. Culture norms and values (teacher as expert) / cultural norms and values (the teacher is the same as an expert).

6. The principal needs to convince the teacher and parents of students and the community, that no matter how great the teacher and the school will not be able to make outstanding children without the support of parents and the community and vice versa.

7. Classroom culture (not viewed as welcoming to parents) / class culture factors that are not open welcome parents as guests.

8. Past experiences (negative experiences with school) / past experience factors (negative experiences with school).

\section{DISCUSSION}

Participation is the process of externalizing the individual, as explained by Berger in (Çoruk, 2018), that the externalization is a continuous surpassing human presence into the world. In the process of externalization according to Berger, it is a necessity because humans in practice cannot stop from the process of self-pouring into the world. Humans will move out expressing themselves in the world around them. Participation as a process of social interaction is determined by the objectivity of individuals in the intersubjective world that can be distinguished by the socio-cultural conditions of the school.

Human resource development in Indonesia still has to catch up with other developed countries. However, efforts to increase the capability of human resources in Indonesia until now still reap criticism and challenges. UNDP data shows that in 2015, Indonesia's HDI was better than the previous year which was 0.689 , but it was still ranked 113 out of 188 countries. Data shows that Indonesia HDI from 1980 continued to rise above Vietnam, but still remained below Thailand. This shows that the Government of Indonesia still needs to increase efforts to develop human resources in the field of education (Hadiyanto, Santoso, Suryadi, \& Zulaikha, 2017).

Community involvement or other names in educational institutions is often called Public Relations or community relations which is a translation of the term public relations or PR. These two terms will be used interchangeably. It consists of several forms of communication held between the organization concerned and anyone with an interest in it (Çoruk, 2018). According to the dictionary definition of the Institute of Public Relations (IPR), a leading public relations institution in the UK and Europe:

"PR is the overall effort that is carried out in a planned and continuous manner in order to create and maintain good intentions and mutual understanding between an organization and its entire audience". So, public relations is a series of activities organized in such a way as a series of integrated campaigns or programs, and all of them take place on an ongoing and regular basis. Public relations activities cannot be done at random or impromptu. (Peltola, 2017)

The purpose of public relations itself is to ensure that the good intentions and gait of the organization concerned are always understood by other interested parties (or, commonly referred to as all "audiences" or the public). According to the association of experts and practitioners of public relations (HUMAS) who become one in the International Public Relations Association (IPRA) provides a definition of the performance of public relations (PR) is a typical management function that supports the coaching and maintenance of a common path between the organization and its public regarding communication, understanding, acceptance and cooperation, involving information and responses in relation to public opinion; establishing and emphasizing management responsibility to serve the public interest; sustain management in following and utilizing change 
effectively, acting as an early warning system in helping trends and conducting research and communication techniques that are healthy and ethical as the primary means (Assumpta, 2002 ).

The understanding of public relations management is a process in handling planning, organizing, communicating, and coordinating seriously and rationally in an effort to achieve the shared goals of the organization or institution it represents. And to realize it all a lot of things that must be done by public relations in an educational institution ( Ratminto, 2006) prepared in such a way to convey and inform new things to the community so that all levels of society can be reached. This collaboration between various layers of society is assumed to minimize the obstacles that might arise in connection with the stipulation of a policy from the government.

George R. Terry put forward four management functions that broadly include:

a. Planning

This is as the planning concept proposed by Adolph Matz and Milton. F " planning is basic to the management process, a process of sensitizing an organization to external opportunities and threats, of determining desirable and possible objectives, and of deploying resources to match the objectives ." (Tatli et al., 2018).

b. Organizing

Organizing is intended to classify the activities required, namely the determination of the organizational structure, as well as the duties and functions of each unit in the organization, organizing can also be formulated as a whole of management activities in grouping people and their respective responsibilities with the aim of creating useful and effective activities. effective in achieving predetermined goals.

\section{c. Mobilization}

According to Terry, as quoted by Syaiful Sagala, defining actuating means stimulating group members to carry out tasks with enthusiasm and good will. The task of mobilizing is carried out by the leader, therefore the principal's leadership is a very important role in moving his personnel to carry out the school work program. Then according to Keith Davis the move is the ability of the leader to persuade people to achieve the goals that have been set with enthusiasm. So the leader moves with enthusiasm and followers also work with enthusiasm. As for the implementation of mobilizing the relationship between the school and the community, attention needs to be paid to coordination between various parts and activities, and in the use of time there needs to be synchronization.

d. Evaluation

Public relations can be evaluated on two criteria: first, its effectiveness, namely to what extent the goals have been achieved, for example whether the community really feels involved in the problems faced by schools, is there attention to the progress of their children at school, whether they have shown concern for school success, whether they already want to provide input for school improvement, and so on. Second, the efficiency, namely to what extent existing or potential resources that have been used properly for the benefit of community relations activities. This evaluation can be done at the time the activity process is in progress or at the end of a program to see to what extent it is successful. (Fordham, 2015).

In Government Regulation No. 39 of 1992 CHAPTER III article 4 community participation / participation may take the form of:

a) Establishment and operation of educational units in the school education channel or non-school education channel, in all types of education except official education, and at all levels of education in the school education pathway;

b) Procurement and providing assistance of educational staff to carry out or help carry out teaching, mentoring and / or training of students;

c) Procurement and providing expert assistance to assist in the implementation of teaching and learning activities and / or research and development;

d) Procurement and / or implementation of educational programs that have not been held and / or implemented by the Government to support national education;

e) Provision of funds and assistance that can be in the form of endowments, grants, donations, loans, scholarships, and other similar forms;

f) Procurement and assistance of rooms, buildings and land to carry out teaching and learning activities;

g) Procurement and distribution of textbooks and educational equipment to carry out teaching and learning activities;

h) Providing opportunities for internships and / or job training;

i) Providing management assistance for organizing education units and developing national education;

j) Giving thoughts and considerations regarding the determination of policies and / or the implementation of educational development;

k) Providing assistance and cooperation in research and development activities; and

1) Participation in education and / or research programs conducted by the Government at home and / or abroad.

Decentralization of education requires community participation. In this case the purpose of participation as an effort to improve quality in educational units is quite varied. The participatory form is in School Based Management, parental participation in quality programs, school committees, school funding, overcoming children's problems, participation in school discipline, educational participation in student perspectives and teacher participation in school resilience.

\section{A. Forms of Community Participation : \\ 1. Participation in SBM \\ Form of activity:}

- The community negotiates with the school. 
- The government provides school infrastructure.

- The school committee participates actively.

- Utilization of existing potential

- The community has mutual cooperation

2. Community participation in education

- HR readiness professionally.

- Stakeholders support the school program.

- Attending school meetings to find out student development.

- Help students learn

- Looking for other sources / supporters to solve educational problems

B. Problems encountered:

1. In community participation in School Based Management (SBM). Problems that appear based on the participation ladder not all schools are able to move the community participation at the highest ladder

2. In community participation in education, a problem that has not been seen by all communities, especially parents in schools, is that they are actively involved in the development of education.

C. Efforts to increase community involvement in early childhood education institutions.

Some of the efforts that can be made are as follows: To overcome various obstacles in the implementation of cooperative relations with parents of students / community viewed from the parent factor, the school must carry out various activities. In this connection the Association of American Parents and Teachers (PTA) has created the same national standards and also allows for the development of parents of students, namely:

1. Communicating between home and school is regular, two-way, and meaningful.

2. Enhanced parenting skills are supported.

3. Parents play an integral role in helping student learning.

4. Parents are accepted at school and their support and assistance is needed.

5. Parents are full partners in making decisions that affect families and children.

6. Community resources are used to strengthen schools, families and student learning.

7. Persuasion to the community in the policies that are carried out will actually benefit the community itself, both in the short and long term.

8. Encourage the community to participate through a series of activities.

9. Linking community participation with better bureaucratic services.

10. Use key community figures who have large audiences to participate in policies, so that most people who become followers also participate in the policies implemented.

11. Linking community participation in implementing policies with their interests. People really need to be believed, that there are many of their interests that are well served, if they participate in wisdom.

12. Recognizing the community to participate in the policies that have been legally established, is one form of the implementation and realization of community aspirations. (Eka Sapti Cahya Ningrum, 2016).

\section{CONCLUSION}

$\mathrm{K}$ OLICY education that is from people for people, and therefore it promotes community participation in education is very important. This is not easy to make people participate in the implementation of education policies, these obstacles can come from the government such as weak commitment of decision makers in the area to involve the community, weak human resources, weak budget support, and from the community in the form of lack of openness from the community, apathy and No the existence of public trust in the government. Whereas efforts to overcome these problems can be like offering sanctions and gifts for active community participation, providing counseling about the benefits of the community's role, using figures in the community as other movers, explaining their benefits and appreciating every aspiration from the community.

\section{REFERENCES}

[1] Abal1, Y., \& Kaan, M. (2018). An Analysis of Graduate Theses on Early Childhood Education: The Case of Turkey. 10 (5), 583-590. https://doi.org/10.26822/iejee.2018541307

[2] Çoruk, A. (2018). School Principals' Opinions about Public Relations Practices on Schools * 14 (2), https://doi.org/10.29329/ijpe.2018.139.10

[3] Eka Sapti Cahya Ningrum. (2016). Maximizing the Role of Public Relations in Early Childhood Education Institution. 1-14.

[4] Fordham, H. (2015). Disembodied creativity: The role of action research in moderating educator expectations of marketing and public relations students. 12 (4).

[5] Gleason, JP, \& Violette, JL (2012). Integrating Service Learning into Public Relations Coursework: Applications, Implications, Challenges, and Rewards. 24 (2), 280-285.

[6] Hadiyanto, Santoso, Y., Suryadi, \& Zulaikha, S. (2017). Autonomy and Community Participation On the Implementation of School-Based Management in The City of South Tangerang. Advances in Social Science, Education and Humanities Research, 118, 1126-1131.

https://doi.org/10.1016/j.cjph.2018.03.003 
[7] Kiewra, C., \& Veselack, E. (2016). Playing with Nature: Supporting Preschoolers' Creativity in Natural Outdoor Classrooms. International Journal of Early Childhood Environmental Education, 4 (1), 70-95.

[8] Peltola, A. (2017). Lead time: An examination of workplace readiness in public relations education.

[9] Tallent, RJ, \& Barnes, JJ (2015). Think Bubbles and Socrates: Teaching Critical Thinking to Millennials in Public Relations Classes. 3 (7), 435-441. https://doi.org/10.13189/ujer.2015.030702

[10] Tatli, Z., Stylianidou, F., Glauert, E., Rossis, D., Compton, A., Cremin, T., Kaan, M. (2018). A Study on the Relationship between Six-Year-Old Children 's Creativity and Mathematical Ability. World Journal of Education, 10 (1), 1-8. https://doi.org/10.5430/wje.v6n5p1 